\title{
Optimization of polyethylenimine-mediated transient transfection using response surface methodology design
}

\author{
Qiangyi Fang ${ }^{1} \varangle \cdot$ Bingqian Shen ${ }^{2}$ \\ 1 Shanghai Institutes for Biological Sciences, Chinese Academy of Sciences, Shanghai, China \\ 2 College of Pharmaceutical Sciences, Nankai University, Tianjin, China \\ $\triangle$ Corresponding author: hicell@gmail.com \\ Received March 6, 2010 / Accepted May 26, 2010 \\ Published online: September 15, 2010 \\ (c) 2010 by Pontificia Universidad Católica de Valparaíso, Chile
}

\begin{abstract}
Response surface methodology was undertaken to optimize the polyethylenimine-mediated transient transfection of suspension cultured HEK 293-F cells. A total of 15 combinations were designed according to Box-Behnken design to identify the effects of DNA concentration, polyethylenimine concentration and incubation time on transient transfection efficiency. The highest integral optic density of green fluorescent protein presenting r-protein yield was accessed using a DNA concentration of $1.75 \mu \mathrm{g} / \mathrm{mL}$, a polyethylenimine concentration of $10.5 \mu \mathrm{g} / \mathrm{mL}$, and an incubation time of $11.8 \mathrm{~min}$. Analysis of variance demonstrated that the experimental values fit well with a quadratic model. The RSM-optimized transient transfection resulted in greater production of human tissue prokallikrein (TproK) than non-RSMoptimized conditions: protein yield was $32.0 \mathrm{mg} / \mathrm{L}$ and the maximum viable cell density reached $3.57 \times 10^{6}$ cells $/ \mathrm{mL}$ in a $5 \mathrm{~L}$ stirred-tank bioreactor culture.
\end{abstract}

Keywords: bioreactor, human tissue kallikrein, transient gene expression

\section{INTRODUCTION}

Stable expression technologies, based on the transgene integrations into the host genome, are currently the most important methods to produce complex recombinant proteins in mammalian cells. The development of these technologies has been tedious and costly, involving a considerable investment of time, labor, materials and equipment. Faster methods of generating proteins are needed for earlier evaluations of protein drug candidates and for analysis and screening in high-throughput formats such as proteomic research. Transient gene expression (TGE) in mammalian cells such as Chinese hamster ovary $(\mathrm{CHO})$ cells and HEK 293 cells are considered wellsuited to fill these needs, with the capabilities to generate milligrams to grams of products within a relatively short timeframe (Pham et al. 2006; Han et al. 2007). Due to factors such as costs of materials, simplicity in handling and facility in large-scale operations, transfection with calcium phosphate and polyethylenimine (PEI) have 
been the most widely used approaches today among numerous commercially available transfection agents (Schlaeger and Christensen, 1999). HEK 293 is the most commonly used cell line for large-scale transient transfection for its advantages such as higher transfectability, suspension cultivation in serum-free conditions, and cost-effective scalability (Han et al. 2007). Yields of transiently-expressed protein from 0.5 to $20 \mathrm{mg} / \mathrm{L}$ have been reported after 5 to 7 days post-transfection in HEK 293 cells (Jordan et al. 1996; Wurm and Bernard, 1999; Girard et al. 2002; Derouazi et al. 2004; Baldi et al. 2005; Rosser et al. 2005; Han et al. 2007).

To explore the full potential of TGE, a relatively large effort has been made to optimize PEl-mediated gene delivery into various cell types (Boussif et al. 1995; Ogris et al. 1998; Kichler et al. 2001; Parham et al. 2001; Durocher et al. 2002; Derouazi et al. 2004; Wulhfard et al. 2008). However, these methods have not tested the effect of varying combinations of the factors involved. Response surface methodology (RSM) is a mathematical and statistical technique used to develop and optimize the evaluation of the relative significance of multiple factors in the presence of complex interactions (Gonen and Aksu, 2008). With RSM, a minimal number of experiments can be performed to optimize a process. We employed this approach to optimize DNA and PEI concentrations and complex formation time for PEI-mediated transient transfection.
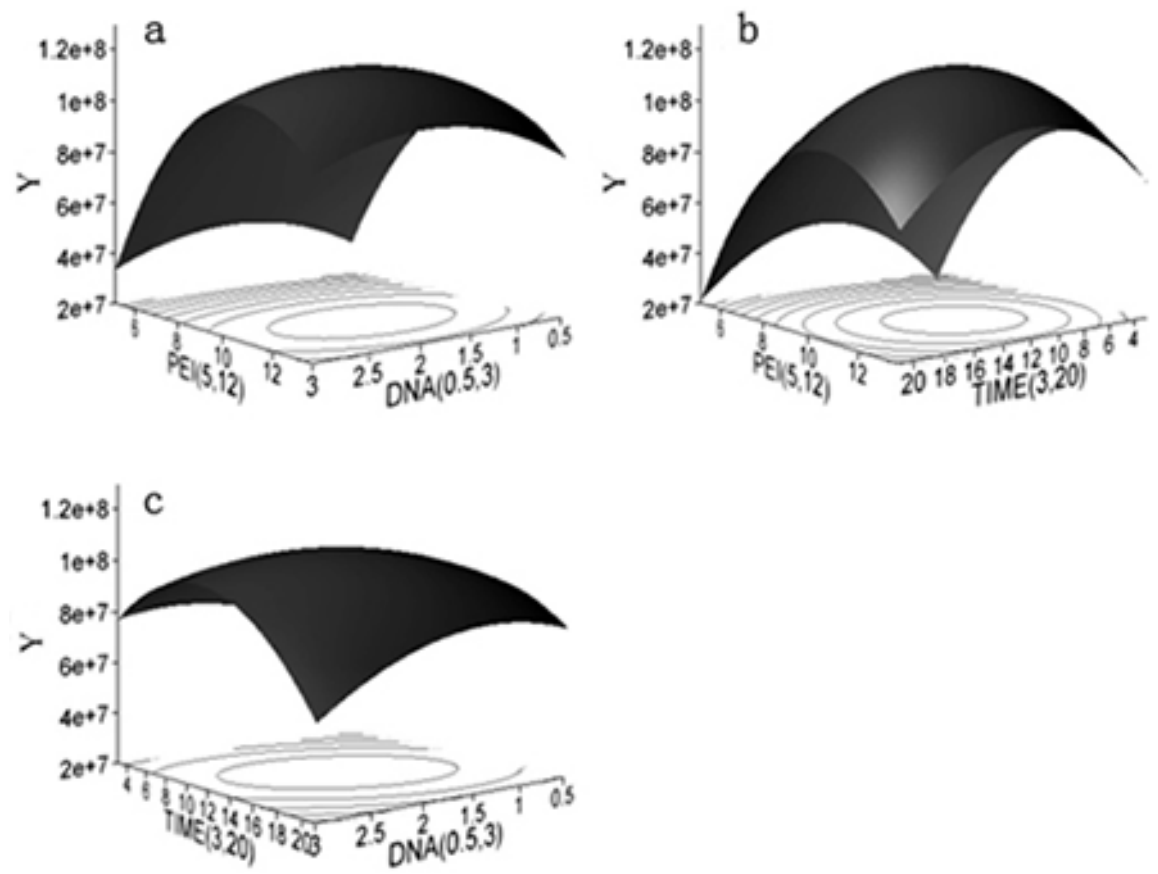

Fig. 1 Three-dimensional plot for value of IOD.(a) Function of PEI concentration and DNA concentration (complex formation time $=11.8 \mathrm{~min}$ ). (b) Function of PEI concentration and time of complex formation (DNA $=1.75 \mu \mathrm{g} / \mathrm{mL}$ ). (c) Function of DNA concentration and complex formation time $(\mathrm{PEI}=10.5 \mu \mathrm{g} / \mathrm{mL})$. 
In this paper, we report the application of RSM optimization to the PEI-mediated transient transfection of HEK 293-F cells to improve the production of human tissue prokallikrein (TproK), the precursor of human tissue kallikrein (hTK), which is widely expressed in diverse tissues and implicated in a range of normal physiologic functions from the regulation of blood pressure and electrolyte balance to tissue remodeling, prohormone processing, neural plasticity, and skin desquamation (Borgono et al. 2004). The transient-expressed TproK was then successfully purified using scalable chromatographic processes. Recombinant TproKs and hTKs were generated in $E$. coli, but with dramatically diminished activity (Angermann et al. 1989; Lu et al. 1996), because proteins produced by prokaryotes lack post-translational modifications. Otherwise, the glycoforms produced by non-human cell lines such as $\mathrm{CHO}$ and NSO are different from those of humans (Jefferis, 2001). It is important to be able to produce native proteins to evaluate the functions and clinical interests of TproK and other proteins with transient expression.

\section{MATERIALS AND METHODS}

\section{Materials}

HEK 293-F cells (Invitrogen) were adapted to suspension culture in LCHL-PF medium, a proprietary protein-free medium containing amino acids, vitamins, trace elements, water soluble fatty acid and cholesterol. The concentrations of glucose and glutamine were 30.0 and $7.5 \mathrm{mM}$, respectively. The maximal cell density was $3.7 \mathrm{x}$ $10^{6} \mathrm{cells} / \mathrm{mL}$ with an inoculation of $3.0 \times 10^{5}$ cells $/ \mathrm{mL}$. Cells were grown in 100 to 1000 $\mathrm{mL}$ shaker flasks on a rotary shaker $(90 \mathrm{rpm})$ at $37^{\circ} \mathrm{C}$ in a $5 \% \mathrm{CO}_{2}$ atmosphere and passaged every 3 days. Unless specified, all reagents were purchased form Sigma Chemical Co.

\section{Expression vector}

The full-length cDNA encoding TproK in prokaryotic expression vector p6183-hTK, a generous gift from Prof. Lee Chao of the Medical University of South Carolina, was amplified using polymerase chain reaction (PCR). A consensus Kozac translation initiation sequence and a Notl restriction site were introduced using the 5' primer (5'TGCGGCCGCCGATGTACGGGCCAGATATAC-3') to facilitate cloning. A Sacll restriction site was also introduced to the 3' primer (5'CTCCGCGGTAGAGCCCCAGCTGGTTCTTTC-3'). The PCR products were digested with Notl and Sacll, and then cloned into the mammalian expression vector pCMV7. Plasmid pEGFP-N1, which contains a strong CMV-immediate early promoter, was used in the optimization of process parameters. Vectors were purified with EndoFree Plasmid Mega Kit (Qiagen) according to manufacturer's protocol and stored at $-20^{\circ} \mathrm{C}$ in TE buffer (10 mM Tris-HCl, 1 mM EDTA, pH 7.4).

Table 1. Levels of experiments variables.

\begin{tabular}{ccccc}
\hline Symbol & Parameters (unit) & \multicolumn{3}{c}{ Levels } \\
\hline & & -1 & 0 & 1 \\
$X_{1}$ & DNA $(\mu \mathrm{g} / \mathrm{mL})$ & 0.5 & 1.75 & 3 \\
$X_{2}$ & PEI $(\mu \mathrm{g} / \mathrm{mL})$ & 5 & 8.5 & 12 \\
$X_{3}$ & Incubation time $(\min )$ & 3 & 11.5 & 20 \\
\hline
\end{tabular}




\section{Optimization of PEI-mediated transient gene expression with RSM design}

Linear PEI (25 kD, Polysciences) was dissolved in distilled water at $1 \mathrm{mg} / \mathrm{mL}(\mathrm{pH} 6.8)$ and stored at $-80^{\circ} \mathrm{C}$ after $0.22 \mu \mathrm{m}$ filtration. Twenty minutes before transfection, exponentially growing HEK 293-F cells in shaker flasks were harvested by centrifugation and gently resuspended to approximately $1.1 \times 10^{6}$ cells $/ \mathrm{mL}$ in low calcium $(100 \mu \mathrm{M}) \mathrm{RPMI} 1640$ to inoculate 6-well plates with $1.35 \mathrm{~mL}$ of cells per well. PEI/pEGFP-N1 complexes were prepared by gentle mixing of $75 \mu \mathrm{L} p E G F P-N 1$ and $\mathrm{PEl}$ of varying concentrations in $150 \mathrm{mM} \mathrm{NaCl}(\mathrm{pH} \mathrm{6.5)}$ ) and incubating for 3 to $20 \mathrm{~min}$. To initiate transfection, $150 \mu \mathrm{L}$ of the complexes were added to corresponding wells at appropriate time points. After $4 \mathrm{hrs}$ of orbital shaking $(90 \mathrm{rpm}), 3 \mathrm{~mL}$ LCHL-PF medium was added to each well for 48 hrs post-transfection culture. Photographs were taken with a fluorescence microscope under the same conditions and transfection efficiency was quantified by the integral fluorescence of the translational product green fluorescent protein (GFP). The integral optic density (IOD), representing the overall expression level of the translational product GFP in each transfection condition, was calculated by Image-Pro Plus (Media Cybernetics, Inc.), as our previous work (Han et al. 2007).
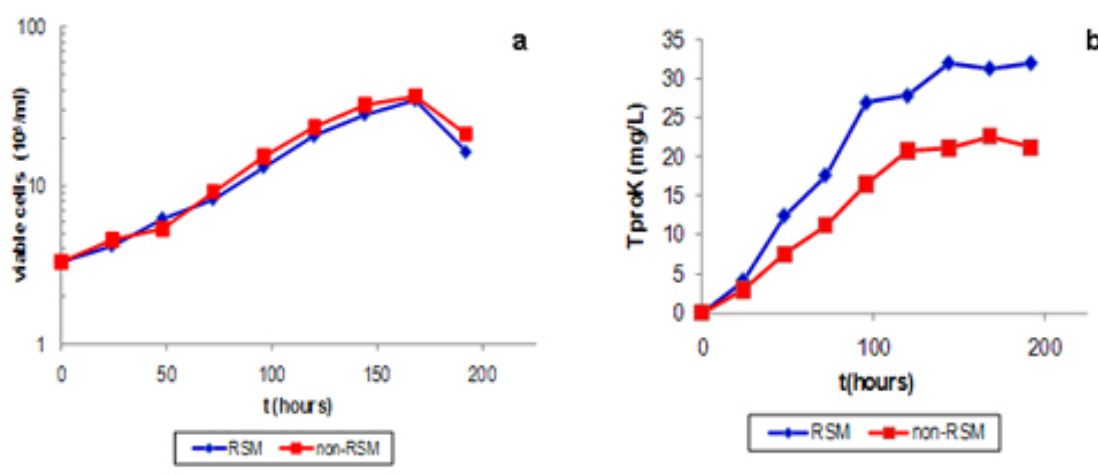

Fig. 2 RSM and non-RSM-optimized post-transfection expression of TproK in shaker flasks.(a) Cell growth curves in the post-transfection culture with RSM and non-RSM-optimized methods.(b) TproK increase curves in the post-transfection culture with RSM and non-RSMoptimized methods.

Statistical analysis and experimental design were performed using JMP software Version 6 (SAS institute Inc., USA). After the ranges of variables were preliminarily screened (data not shown), response surface methodology was adapted to investigate the combined effect of three independent variables $\left(X_{i}\right)$, i.e. DNA concentration $\left(X_{1}=0.5-3 \mu \mathrm{g} / \mathrm{mL}\right)$, PEl concentration $\left(X_{2}=5-12 \mu \mathrm{g} / \mathrm{mL}\right)$, and incubation time $\left(X_{3}=3-20 \mathrm{~min}\right)$. The three levels of variables in each treatment are shown in Table 1. A total of 15 combinations including 3 replicates of the center point were executed in random order according to the Box-Behnken configuration shown in Table 2. A second order polynomial equation was used to correlate the independent process variables, with the outcome of IOD. Experiments were also carried out in duplicates to provide the mean of IOD in Table 2. 


\section{Comparison of expression level between RSM-optimized and non-RSM- optimized conditions in shaker flasks}

In order to identify the effect of RSM optimization on TproK transient expression, a comparison study was made at a small scale in LCHL-PF medium between the conditions of transfection optimized in the RSM approach and those obtained through factor screening (non-RSM-optimized) as we described previously (Han et al. 2007), but with the TproK transient expression. The RSM-optimized DNA/PEl/time combination was $1.75 / 10.5 / 11.8(\mu \mathrm{g} / \mathrm{mL}, \mu \mathrm{g} / \mathrm{mL}, \mathrm{min})$, while the non-optimized combination was 1.0/6.0/30 $(\mu \mathrm{g} / \mathrm{mL}, \mu \mathrm{g} / \mathrm{mL}, \mathrm{min})$. The PEI/DNA nitrogen/phosphate $(\mathrm{N} / \mathrm{P})$ ratio was $46.5: 1$

PEI and plasmid DNA (pCMV-TproK) were diluted in $350 \mu \mathrm{l}$ of $150 \mathrm{mM} \mathrm{NaCl}(\mathrm{pH} 6.5)$, separately. The PEI solution was then added to the plasmid solution and vortexed immediately. After an appropriate incubation, the total $700 \mu \mathrm{l}$ of PEI/DNA complex was added to $7 \times 10^{6}$ cells in $6.3 \mathrm{~mL}$ of low-calcium RPMl 1640 . After $4 \mathrm{hrs}$ of incubation on a rotary shaker (90 rpm), $14 \mathrm{~mL}$ LCHL-PF was added for posttransfection cultures. The concentration of TproK and viable cell density were measured every $24 \mathrm{hrs}$ after transfection.

TproK transient expression in 5 L stirred-tank bioreactor with RSM-optimized conditions

Approximately $7.7 \times 10^{8}$ of exponentially growing HEK 293-F cells in shaker flasks were harvested and resuspended in $700 \mathrm{~mL}$ of low-calcium RPMI 1640 to inoculate a 5 L stirred-tank bioreactor (B. Braun, Melsungen, Germany). Operational conditions were set at $50 \%$ of air saturation for dissolved oxygen, $70 \mathrm{rpm}$ for mixing with a fourblade segmented impeller, and $\mathrm{pH} 7.05$ with intermittent $\mathrm{CO}_{2}$ addition to the aeration gas mixture. In a $250 \mathrm{~mL}$ glass flask, $70 \mathrm{~mL}$ of PEl/pCMV-TproK complexes was

Table 2. Matrix of experimental Box-Behnken design for TGE and IOD experimental yield.

\begin{tabular}{cccccc}
\hline $\begin{array}{c}\text { Treatment } \\
\text { Trial }\end{array}$ & $\begin{array}{c}\text { DNA } \\
\text { concentration }\end{array}$ & $\begin{array}{c}\text { PEI } \\
\text { concentration }\end{array}$ & $\begin{array}{c}\text { Incubation } \\
\text { time }\end{array}$ & $\begin{array}{c}\text { Mean } \\
\text { of IOD }\end{array}$ & $\begin{array}{c}\text { Predicted } \\
\text { IOD value }\end{array}$ \\
\hline 1 & -1 & -1 & 0 & 26538232 & 33182740.5 \\
2 & 1 & 1 & 0 & 104898040 & 98253531.5 \\
3 & 0 & 1 & 1 & 81763924 & 86908266.5 \\
4 & 1 & 0 & 1 & 58960936 & 60461102 \\
\hline 5 & 0 & -1 & -1 & 21728540 & 16584197.5 \\
6 & 1 & 0 & -1 & 55708004 & 54207838 \\
\hline 7 & 0 & 1 & -1 & 92422760 & 85377261.5 \\
\hline 8 & -1 & 1 & 0 & 88877288 & 97422952.5 \\
\hline 9 & 0 & 0 & 0 & 106752076 & 107103711 \\
10 & -1 & 0 & 1 & 95942568 & 82252561 \\
\hline 11 & 1 & -1 & 0 & 41897812 & 33352147.5 \\
12 & 0 & -1 & 1 & 19514236 & 26559734.5 \\
13 & 0 & 0 & 0 & 113032128 & 107103711 \\
\hline 14 & 0 & 0 & 0 & 101526928 & 107103711 \\
\hline 15 & -1 & 0 & -1 & 63309276 & 76999283 \\
\hline
\end{tabular}


prepared under vigorous mixing for about 10 min with a Teflon stir bar. The addition of complexes into the bioreactor was completed within $5 \mathrm{~min}$ at a higher stirring rate of $90 \mathrm{rpm}$. During the transfection stage, cell density, concentration of pCMV-TproK, and concentration of PEI were $1.0 \times 10^{6}$ cells $/ \mathrm{mL}, 1.75 \mu \mathrm{g} / \mathrm{mL}$ and $10.5 \mu \mathrm{g} / \mathrm{mL}$, respectively. $1540 \mathrm{~mL}$ LCHL-PF was added $4 \mathrm{hrs}$ later to facilitate the posttransfection cell growth in the bioreactor. Cell growth and concentrations of TproK and major metabolites in the medium were measured daily afterwards.

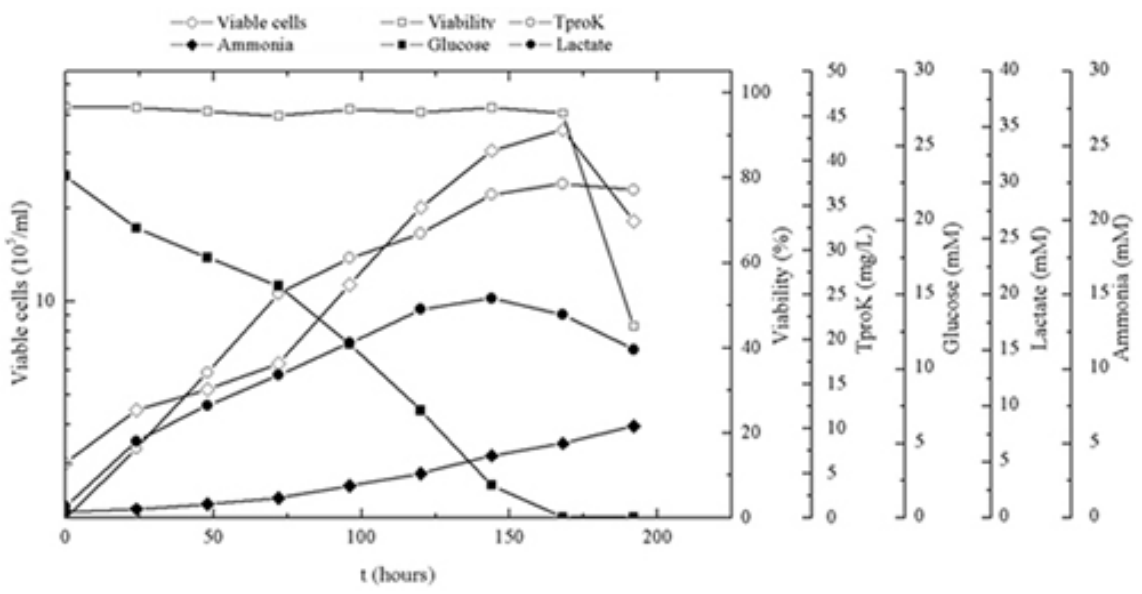

Fig. 3 Post-transfection culture of HEK 293-F cells to express TproK in LCHL-PF medium.

\section{Protein purification}

On the seventh day of post-transfection, $200 \mathrm{~mL}$ of spent medium was cleared by centrifugation at $12,000 \mathrm{rpm}$ for $10 \mathrm{~min}$ and concentrated by diafiltration (molecular weight cutoff $10 \mathrm{kDa}$ ) in $10 \mathrm{mM}$ Tris- $\mathrm{HCl}$ with $1.5 \mathrm{M} \mathrm{(NH4)})_{2} \mathrm{SO}_{4}(\mathrm{pH} 7.5)$. After filtration with $0.4 \mu \mathrm{m}$ membrane, $20 \mathrm{~mL}$ of the concentrate was loaded on to a $1 \mathrm{~mL}$ equilibrated HiTrap Octyl FF column (GE), followed by washing with $10 \mathrm{~mL}$ of diafiltration buffer to remove unbound proteins before elution with $10 \mathrm{mM}$ Tris- $\mathrm{HCl}(\mathrm{pH}$ 7.5). Fractions containing TproK were pooled and dialyzed against $10 \mathrm{mM}$ Tris- $\mathrm{HCl}$ $(\mathrm{pH} 7.5)$ at $4^{\circ} \mathrm{C}$. After loaded on $1 \mathrm{~mL}$ HiTrap Q FF (GE), the proteins was eluted with $500 \mathrm{mM} \mathrm{NaCl}$ in $10 \mathrm{mM}$ Tris- $\mathrm{HCl}(\mathrm{pH} \mathrm{7.5)}$ in a linear gradient of 0 to $100 \%$ over 10 column volumes. Fractions containing TproK were pooled again and dialyzed against $500 \mathrm{mM} \mathrm{NaCl}$ in $50 \mathrm{mM}$ Tris- $\mathrm{HCl}(\mathrm{pH} 7.4)$ at $4^{\circ} \mathrm{C}$ before being loaded on a $1 \mathrm{~mL}$ HiTrap Benzamidine FF (GE). After a washing of 10-15 column volumes, HiTrap Benzamidine FF column was eluted with $5-10$ column volumes of $500 \mathrm{mM} \mathrm{NaCl}$ in 10 $\mathrm{mM} \mathrm{HCl}(\mathrm{pH} 2.0)$. Over-acidification was avoided by adding $100 \mu \mathrm{L}$ of $1 \mathrm{M}$ Tris- $\mathrm{HCl}$ (pH 9.0) to $1 \mathrm{~mL}$ of eluate in each collection tube. Purified TproK was dialyzed against $\mathrm{PBS}$ at $4^{\circ} \mathrm{C}$ overnight, aliquoted, and stored at $-80^{\circ} \mathrm{C}$. All chromatographic steps were performed on an AKTA FPLC system (GE). 


\section{Analytical methods}

Cell density and viability were estimated by the trypan blue dye exclusion method with a hemocytometer. Concentrations of glucose, lactate and ammonium were measured with YSI 2300 STAT PLUS glucose/L-lactate analyzer and Model 95-12 ammonia electrode (Thermo Electron Co.), respectively.

The concentration of recombinant TproK was determined by enzyme-linked immunosorbent assay. Purity of the target protein was assessed by high pressure liquid chromatography. Western blotting was performed after transferring protein bands from SDS-PAGE (12\%) to Hybond ECL nitrocellulose membrane (Amersham).

\section{RESULTS AND DISCUSSION}

\section{Optimization of transfection conditions}

To examine the combined effect of plasmid DNA concentration, PEI concentration and the time of PEI/DNA complex formation, a total of 15 experiments (Table 2) were performed with the use of pEGFP-N1 and a face Box-Behnken design.

Analysis of variance (ANOVA) was important in determining the adequacy and significance of the quadratic model (Table 3). The $R^{2}$ value of the model was 0.9444 , indicating the model was reliability and suggested that only $5.56 \%$ of the total variations were unable to explain by the mathematical model. The model "Probe $>$ F" was 0.0118 less than 0.0500 indicated that the model was statistically significant and there was only a $1.18 \%$ chance that a "Model $F$-value" this large could occur due to noise. In the manner, the effect of $X_{2}$, the second order effect of $X_{2}$ and $X_{3}$ (the value of "Probe > F" were $0.0009,0.0086,0.0133$ respectively) implied that they were important model terms.

Application of RSM resulted in the following relationship between IOD and variables:

IOD $=-241129263.6+42101866.8 X_{1}+48952019.2 X_{2}+10786626.8 X_{3}$

$+37781.2 X_{1} X_{2}-1049009.6 X_{1} X_{3}-70962.4 X_{2} X_{3}-8616971.6\left(X_{1}\right)^{2}$

$-2292804\left(X_{2}\right)^{2}-348228.4\left(X_{3}\right)^{2}$

Here, $X_{1}, X_{2}$ and $X_{3}$ represent the concentration of DNA in $\mu \mathrm{g} / \mathrm{mL}$, the concentration of $\mathrm{PEl}$ in $\mu \mathrm{g} / \mathrm{mL}$ and the complex formation time in minutes, respectively. Threedimensional graphs, showing the IOD responses to the concentrations of DNA and $\mathrm{PEI}$, and complex formation time are presented in Figure 1.

The PEI concentration clearly had a more dynamic effect (within the range tested) on the outcome of transient expression of GFP than DNA concentration (Figure 1a). A similar observation could be made in the plot of $\mathrm{PEI}$ concentration against complex formation time (Figure 1b). The value of IOD rose to a maximum when PEI concentration was increased to $10.5 \mu \mathrm{g} / \mathrm{mL}$, and then started to decline in both cases. 
Although the concentration of DNA contributed to the outcome of IOD to a lesser degree according to the model, an optimal concentration of $1.75 \mu \mathrm{g} / \mathrm{mL}$ could be identified from its tested concentration range of 0.5 to $3 \mu \mathrm{g} / \mathrm{mL}$. The complex formation time affected IOD moderately, and optimized results were obtained with a complex formation time of $11.8 \mathrm{~min}$. To summarize, the optimal conditions for these independent variables could be drawn from these statistically designed experiments: $1.75 \mu \mathrm{g} / \mathrm{mL}$ for DNA, $10.5 \mu \mathrm{g} / \mathrm{mL}$ for $\mathrm{PEI}$, and $11.8 \mathrm{~min}$ for the time of incubation.

\section{Comparison of transient expression level between RSM-optimized and non- RSM- optimized PEI/DNA/time combination in shaker flasks}

PEI and plasmid DNA (pCMV-TproK) were mixed and vortexed immediately for an appropriate complex formation time. The RSM-optimized DNA/PEI/time combination was $1.75 / 10.5 / 11.8(\mu \mathrm{g} / \mathrm{mL}, \mu \mathrm{g} / \mathrm{mL}$, minutes), respectively, while the non-RSMoptimized combination was 1.0/6.0/30 $(\mu \mathrm{g} / \mathrm{mL}, \mu \mathrm{g} / \mathrm{mL}$, minutes), respectively.

Transfected with RSM-optimized conditions, a minor difference in post-transfection cell growth was observed, probably due to the higher toxicity of PEI at a higher level in the RSM-optimized culture (Figure 2a). The maximum viable cell density reached $3.5 \times 10^{6}$ cells $/ \mathrm{mL}$ for RSM-optimized conditions and $3.7 \times 10^{6}$ cells $/ \mathrm{mL}$ for the nonRSM-optimized conditions. In this comparison study at a small scale in shaker flasks, however, a greater gain in TproK transient expression was realized using the transfection conditions from RSM optimization over those from factor screening, representing a yield increase of $41 \%$ from $22.6 \mathrm{mg} / \mathrm{L}$ to approximately $32.0 \mathrm{mg} / \mathrm{L}$ (Figure 2b).

\section{Batch culture of transfected HEK 293-F cells in $5 \mathrm{~L}$ stirred-tank bioreactor}

Following inoculation of a $5 \mathrm{~L}$ stirred-tank B. Braun bioreactor with exponentially growing HEK 293-F cells, PEl/pCMV-TproK complexes were prepared under vigorous mixing using the RSM-optimized conditions and added to the bioreactor within 5 min. During the transfection stage, cell density and bulk concentrations of pCMV-TproK and PEI were $1.0 \times 10^{6}$ cells $/ \mathrm{mL}, 1.75$ and $10.5 \mu \mathrm{g} / \mathrm{mL}$, respectively.

Table 3. Analysis of the model.

\begin{tabular}{cccc}
\hline Source & DF & F ratio & Probe $>$ F \\
\hline Mode & 9 & 9.4429 & $<.0001$ \\
$X_{1}$ & 1 & 0.0030 & 0.9584 \\
$X_{2}$ & 1 & 50.0968 & 0.0009 \\
$X_{3}$ & 1 & 0.3977 & 0.5560 \\
$X_{1} X_{2}$ & 1 & 0.0007 & 0.9805 \\
$X_{1} X_{3}$ & 1 & 2.9853 & 0.1446 \\
$X_{2} X_{3}$ & 1 & 0.1071 & 0.7567 \\
$\left(X_{1}\right)^{2}$ & 1 & 4.0212 & 0.1013 \\
$\left(X_{2}\right)^{2}$ & 1 & 17.4989 & 0.0086 \\
$\left(X_{3}\right)^{2}$ & 1 & 14.0414 & 0.0133 \\
\hline
\end{tabular}


During the post-transfection culture of 8 days, the maximal viable cell density reached $3.57 \times 10^{6}$ cells $/ \mathrm{mL}$ on day 7 (Figure 3 ). Secretion of TproK reached a plateau on day 6 with a maximum yield of $37.5 \mathrm{mg} / \mathrm{L}$ on day 7 . Glucose consumption was found to be dramatic and exhausted on day 7. Accumulation of L-lactate reached a maximum of $19.7 \mathrm{mM}$ on day 6 and then started to decline during the last 2 days. A steady increase of ammonium accumulation was also observed, with a final concentration of $6.17 \mathrm{mM}$ at the end of the post-tranfection culture. Maximizing the utilization of glucose and minimizing the formation of ammonium were considered appropriate approaches to further improvement of TproK production.

We repeated the experiments in $2 \mathrm{~L}$ and $30 \mathrm{~L}$ stirred-tank bioreactors. The maximum viable cell density and TproK yield were similar, which were $3.45 \times 10^{6}, 3.37 \times 10^{6}$ cells/mL and 35.1, $42.1 \mathrm{mg} / \mathrm{L}$.
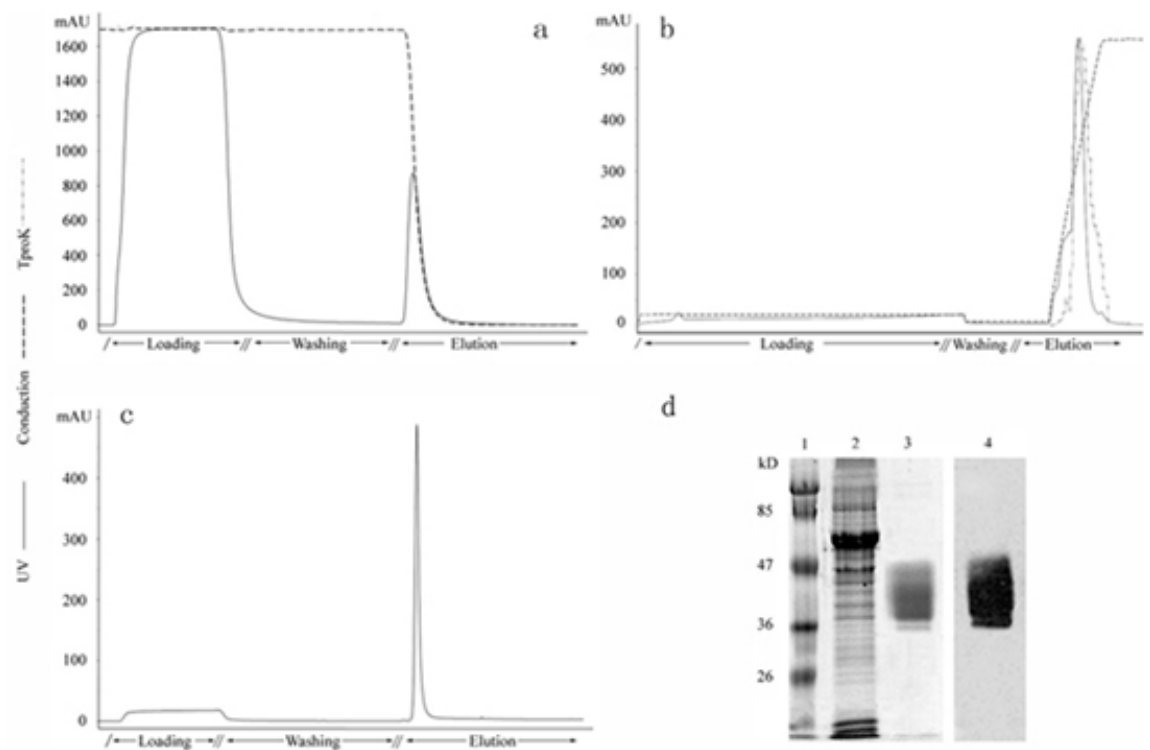

d

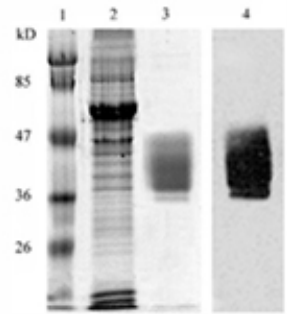

Fig. 4 Chromatographic purification of transiently expressed TproK. (a) Octyl Sepharose chromatography. (b) Q-Sepharose chromatography. (c) Benzamidine Sepharose affinity chromatography. (d) SDS-PAGE and Western blotting. Lane 1: protein markers; Lane 2 and 3: concentrated spent medium and purified TproK; Lane 4: Western Bolt.

\section{Purification of transiently expressed recombinant human TproK}

Following successive chromatographic operations on columns of Octyl Sepharose (Figure 4a) and Q-Sepharose column (Figure 4b) and benzamidine-Sepharose (Figure 4c), as described above, fractions containing TproK as analyzed by enzymelinked immunosorbent assay were pooled and dialyzed against PBS at $4^{\circ} \mathrm{C}$. Size exclusion high pressure liquid chromatography analysis on the TproK indicated a purity of greater than 95\%. The purified protein was shown to be 35 to $45 \mathrm{kDa}$ as defused bands, and recognized by the polyclonal antiserum against TproK (Acris, German), in SDS-PAGE and western blotting most likely due to different degrees of 
glycosylation (Figure 4d). The overall recovery yield was approximately $54 \%$ of the starting material.

\section{CONCLUDING REMARKS}

In contrast to stable gene expression, transient gene expression involves short-term rprotein production, typically for up to 10 days post-transfection in the absence of genetic selection of the plasmid DNA (Baldi et al. 2007). In our work, a higher level of TproK was successfully transiently expressed in HEK 293-F cells and then purified chromatographically. In this study, an RSM-optimized transient transfection method for suspension culture HEK 293-F cells was investigated. The interaction between independent variables (DNA concentration, PEI concentration and incubation time) was taken into account using RSM optimization, and effective combined results were accessed. The PEI concentration of $10.5 \mu \mathrm{g} / \mathrm{mL}$ was higher than in previously reported results. Fortunately, PEI at $10.5 \mu \mathrm{g} / \mathrm{mL}$ has little influence in HEK 293-F cell growth according to our work (Figure 2). Incubation time was shorter compared to the previous results (approximately 15 to $30 \mathrm{~min}$ ), perhaps as a result of the high concentration of PEI and DNA forming nano-particles more quickly. Whether the result is suitable for transient transfection of other cell lines should be studied further.

\section{REFERENCES}

ANGERMANN, A.; BERGMANN, C. and APPELHANS, H. Cloning and expression of human salivary-gland kallikrein in Escherichia coli. Biochemical Journal, September 1989, vol. 262, part 3, p. 787-793.

BALDI, Lucia; HACKER, David L.; ADAM, Myriam and WURM, Florian M. Recombinant protein production by large-scale transient gene expression in mammalian cells: state of the art and future perspectives. Biotechnology Letters, May 2007, vol. 29, no. 5, p. 677-684. [CrossRef]

BALDI, L.; MULLER, N.; PICASSO, S.; JACQUET, R.; GIRARD, P.; THANH, H.P.; DEROW, W. and WURM, F.M. Transient gene expression in suspension HEK293 cells: Application to large-scale protein production. In: Animal Cell Technology Meets Genomics. Springer Netherlands, 2005, p. 365-367.

BORGONO, Carla A.; MICHAEL, lacovos P. and DIAMAMDIS, Eleftherios P. Human tissue kallikreins: Physiologic roles and applications in cancer. Molecular Cancer Research, May 2004, vol. 2, no. 5, p. 257-280.

BOUSSIF, O.; LEZOUALCH, F.; ZANTA, M.; MERGNY, M.D.; SCHERMAN, D.; DEMENEIX, B. and BEHR, J.B. A versatile vector for gene and oligonucleotide transfer into cells in culture and in vivo: polyethylenimine. Proceedings of the National Academy of Sciences of the United States of America, August 1995, vol. 92, no. 16, p. 7297-7301.

DEROUAZI, Madiha; GIRARD, Philippe; VAN TILBORGH, Frédéric; IGLESIAS, Keyvan; MULLER, Natalie; BERTSCHINGER, Martin and WURM, Florian M. Serum-free largescale transient transfection of $\mathrm{CHO}$ cells. Biotechnology and Bioengineering, August 2004, vol. 87, no. 4, p. 537-545. [CrossRef]

DUROCHER, Yves; PERRET, Sylvie and KAMEN, Amine. High-level and high-throughput recombinant protein production by transient transfection of suspension-growing human 293-EBNA1 cells. Nucleic Acids Research, 2002, vol. 30, p. e9. [CrossRef]

GIRARD, Philippe; DEROUAZI, Madiha; BAUMGARTNER, Gwendoline; BOURGEOIS, Michaela; JORDAN, Martin; JACKO, Barbara and WURM, Floriam M. 100-liter transient transfection. Cytotechnology, January 2002, vol. 38, no. 1-3, p. 15-21. [CrossRef]

GÖNEN, Ferda and AKSU, Zümriye. Use of response surface methodology (RSM) in the evaluation of growth and copper(II) bioaccumulation properties of Candida utilis in molasses medium. Journal of Hazardous Materials, June 2008, vol. 154, no. 1-3, p. 731738. [CrossRef] 
HAN, Xiangzong; SUN, Lei; FANG, Qiangyi; LI, Dongxiao; GONG, Xianghui; WU, Yuyin; YANG, Shengli and SHEN, Bing Q. Transient expression of osteopontin in HEK 293 cells in serum-free culture. Enzyme and Microbial Technology, July 2007, vol. 41, no. 1-2, p. 133140. [CrossRef]

JEFFERIS, Roy. Glycosylation of human IgG antibodies: Relevance to therapeutic applications. Biopharm International, September 2001, vol. 14, p. 19-21.

JORDAN, Martin; SCHALLHOMN, Annette and WURM, Florian M. Transfecting mammalian cells: Optimization of critical parameters affecting calcium-phosphate precipitate formation. Nucleic Acids Research, February 1996, vol. 24, no. 4, p. 596-601. [CrossRef]

KICHLER, Antoine; LEBORGNE, Christian; COEYTAUX, Emmanuel and DANOS, Olivier. Polyethylenimine-mediated gene delivery: a mechanistic study. The Journal of Gene Medicine, March-April 2001, vol. 3, no. 2, p. 135-144. [CrossRef]

LU, Hsieng S.; HSU, Yueh-Rong; NARHI, Linda O.; KARKARE, Subhash and LIN, Fu-Kuen. Purification and characterization of human tissue prokallikrein and kallikrein isoforms expressed in Chinese hamster ovary cells. Protein Expression and Purification, September 1996, vol. 8, no. 2, p. 227-237. [CrossRef]

OGRIS, M.; STEINLEIN, P.; KURSA, M.; MECHTLER, K.; KIRCHEIS, R. and WAGNER, E. The size of DNA/transferrin-PEI complexes is an important factor for gene expression in cultured cells. Gene Therapy, October 1998, vol. 5, no. 10, p. 1425-1433.

PARHAM, Janet H.; KOST, Tom and HUTCHINS, Jeff T. Effects of pCIneo and pCEP4 expression vectors on transient and stable protein production in human and simian cell lines. Cytotechnology, May 2001, vol. 35, no. 3, p. 181-187. [CrossRef]

PHAM, Phuong Lan; KAMEN, Amine and DUROCHER, Yves. Large-scale transfection of mammalian cells for the fast production of recombinant protein. Molecular Biotechnology, October 2006, vol. 34, no. 2, p. 225-237. [CrossRef]

ROSSER, Mary P.; XIA, Wei; HARTSELL, Steven; McCAMAN, Michael; ZHU, Ying; WANG, Soujuan; HARVEY, Susan; BRINGMANN, Peter and COBB, Ronald R. Transient transfection of CHO-K1-S using serum-free medium in suspension: a rapid mammalian protein expression system. Protein Expression and Purification, April 2005, vol. 40, no. 2, p. 237-243. [CrossRef]

SCHLAEGER, Ernst-Jürgen and CHRISTENSEN, Klaus. Transient gene expression in mammalian cells grown in serum-free suspension culture. Cytotechnology, July 1999, vol. 30, no. 1-3, p. 71-83. [CrossRef]

WULHFARD, Sarah; TISSOT, Stéphanie; BOUCHET, Sophie; CEVEY, Jean; JESUS, Maria de; HACKER, David L. and WURM, Florian M. Mild hypothermia improves transient gene expression yields several fold in Chinese hamster ovary cells. Biotechnology Progress, March-April 2008, vol. 24, no. 2, p. 458-465. [CrossRef]

WURM, Florian M. and BERNARD, Alain. Large-scale transient expression in mammalian cells for recombinant protein production. Current Opinion in Biotechnology, April 1999, vol. 10, no. 2, p. 156-159. [CrossRef]

\section{How to cite this article:}

FANG, Q. and SHEN, B. Optimization of polyethylenimine-mediated transient transfection using response surface methodology design. Electronic Journal of Biotechnology, September 2010, vol. 13, no. 5. http://dx.doi.org/10.2225/vol13-issue5-fulltext-6 